\title{
Pemberdayaan Ekonomi Kelompok Usaha Bersama Untuk Meningkatkan Kesejahteraan Masyarakat (Studi Di Kube Waroh Dusun Penangka Desa Sesaot)
}

\author{
Laili Hurriati \\ ${ }^{)}$Fakultas Ekonomi Universitas Islam Al-Azhar Mataram \\ lailihurriati.86@gmail.com
}

Received: 19 Nopember, 2020; Accepted: 09 Desember 2020; Published: 17 Desember, 2020

\begin{abstract}
Abstrak
Penelitian ini bertujuan untuk mengetahui Pemberdayaan Ekonomi Kelompok Usaha Bersama Untuk Meningkatkan Kesejahteraan Masyarakat Di Kube Waroh Dusun Penangka Desa Sesaot. Penelitian ini menggunakan pendekatan kualitatif karena peneliti bermaksud mendiskripsikan bagaimana Pemberdayaan Ekonomi Kelompok Usaha Bersama Untuk Meningkatkan Kesejahteraan Masyarakat Di Kube Waroh Dusun Penangka Desa Sesaot. Program KUBE Waroh merupakan suatu kegiatan yang menjembatani masyarakat untuk mendapatkan pengetahuan, keterampilan dan pengalaman melalui suatu kelompok yang dibentuk secara bersama guna meningkatkan kualitas sumber daya manusia agar mampu memasuki dunia kerja,. Adapun hasil penelitian ini adalah di ketahui bahwa pemberdayaan ekonomi melalui Implementasi program KUBE pada anggota KUBE Waroh dapat memberikan manfaat yang positif bagi anggotanya, dilihat dari anggota yang sebelumnya tidak mempunyai kegiatan usaha sekarang mempunyai kegiatan usaha yang sekaligus juga berdampak pada perekonomian anggotanya yang sudah meningkat.
\end{abstract}

Kata Kunci: Pemberdayaan Ekonomi; Kelompok Usaha Bersama (KUBE); Kesejahteraan

\begin{abstract}
This study aims to determine the effectiveness of economic empowerement through joint business group (kelompok usaha bersama), hereinafter referred to as KUBE, to improve community welfare in KUBE Waroh, Penangka sub-village of Sesaot Village. This study employs qualitative approach in order to examine how the economic empowerement could improve community welfare in KUBE Waroh, Penangka of Sesaot Village. The KUBE program involves activities which help the community to gain knowledge, skills and experience whereby the activities are delivered by the group established with common goals. By improving the quality of human resources, then, it is hoped that the beneficiaries' access to work will increase too. The result of this study shows that the economic empowerment through the implementation of the KUBE program towards the KUBE Waroh members could bring positive impacts to the members. It is evident from the fact that now the
\end{abstract}


members are becoming economically productive, participating in an economically productive activity, mirroring the increase in the members' economic welfare.

Keywords: Economic empowerment; joint business group (KUBE); economic welfare

\section{PENDAHULUAN}

Pemberdayaan masyarakat sering juga di sebut suatu kegiatan seseorang atau individu yang melakukan kerjasama dengan individu lain dengan membentuk suatu kelompok yang bertujuan untuk menemukan alternative baru dalam rangka membangun kualitas masyarakat. Kegiatan pemberdayaan masyarakat dilakukan dari, oleh dan untuk masyarakat diharapkan mampu menunjang penanggulangan kemiskinan sehingga dapat berjalan efektif.

Pelaksanaan program penanggulangan kemiskinan melalui pemberdayaan masyarakat dapat dilakukan secara berkelompok. Penanggulangan kemiskinan yang berbasis kelompok yang dilakukan masyarakat memerlukan sinergi yang kokoh dan terarah dari pemangku kepentingan dalam bidang tersebut, yaitu pemerintah, swasta dan masyarakat itu sendiri. Salah satunya lewat program kelompok usaha bersama (Kube), yang diluncurkan pemerintah melalui Kementerian Sosial pada tahun 1982.

KUBE adalah kelompok usaha bersama yaitu salah satu program pemerintah yang ada pada kementerian Sosial RI khususnya di Direktorat Jenderal Pemberdayaan Sosial dan penanggulangan. Yang bertujuan untuk memberdayakan masyarakat miskin dengan pemberian modal usaha untuk mengelola usaha ekonomi produktif. Dengan adanya program kelompok usaha bersama ini di harapkan mampu mengurangi permasalahan sosial yang ada di masyarakat. Berbagai keterbatasan itu muncul di tengah masyarakat yang mengalami permasalahan kesejahteraan sosial dan kemiskinan. keterbatasan itu antara lain, menyangkut rendahnya tingkat pendidikan serta terbatasnya kemampuan dan keterampilan yang dimiliki sehingga banyak kendala yang harus dihadapi dalam mencari nafkah atau meningkatkan kesejahteraan keluarga. 
Saat ini terdapat 3.693 KUBE yang ada di Nusa Tenggara Barat, tersebar disemua kabupaten kota terdiri dari kota mataram sebanyak 164 Kube, Lombok barat sebanyak 265, Lombok tengah sebanyak 602 Kube, Lombok timur sebanyak 503 Kube, Lombok utara sebanyak 504 Kube, Sumbawa barat sebanyak 76 Kube, Sumbawa sebanyak 329 Kube, Dompu sebanyak 289 Kube, Bima sebanyak 732 Kube, dan kota Bima sebanyak 229 Kube.

Desa sesaot dusun penangka salah satu desa di kabupaten Lombok Barat yang mampu mewujudkan program pemerintah dalam pengentasan kemiskinan melalui pemberdayaan masyarakat, melalui program Kelompok Usaha Bersama (KUBE) berupa pelatihan pengolahan dan keterampilan. Masyarakat Desa sesaot khususnya yang ada di dusun penangka sebagian masih banyak yang ada pada dibawah garis kemiskinan. Pendapatan yang mereka peroleh tidak cukup untuk memenuhi kebutuhan mereka sehari-hari. Pada umumnya masyarakat yang ada di dusun penangka ini bekerja serabutan dan sebagian menjadi Tenaga Kerja Asing (TKI) serta banyak yang menjadi petani. Pendapatan yang diperoleh tidak mampu untuk memenuhi kebutuhan hidup keluarga yang semakin meningka serta biaya sekolah untuk anak tinggi. Untuk itu perlu adanya terobosan keterampilan baru yang dapat membantu mengentaskan kemiskinan pada keluarga miskin . salah satu tujuan program Kelompok Usaha Bersama (KUBE) membantu memberdayakan masyarakat, terutama masyarakat miskin untuk mengangkat perekonomian mereka untuk mencapai sebuah kesejahteraan masyarakat.

Kube Waroh hadir di tengah-tengah masyarakat Desa Sesaot saat itu, yang bertujuan untuk meningkatkan kesejahteraan masyarakat.. Melalui programprogram yang dicanangkanya seperti program pelatihan dan program keterampilan, diharapkan Kube waroh mampu mengangkat perekonomian masyarakat Dusun Penangke Desa Sesaot demi mencapai sebuah kesejahteraan.

\section{Pendekatan dalam Pemberdayaan Masyarakat}

Menurut Djohani dalam Kusnadi (2005) menyebutkan pemberdayaan masyarakat dimaksudkan mengembangkan kemampuan masyarakat agar secara 
berdiri sendiri memiliki keterampilan untuk mengatasi masalah-masalah mereka sendiri. Pemberdayaan masyarakat adalah upaya untuk menciptakan atau meningkatkan kapasitas masyarakat, baik secara individu maupun berkelompok dalam memecahkan berbagai persoalan terkait upaya peningkatan kualitas hidup, kemandirian dan kesejahteraannya. Direktorat Jenderal Pemberdayaan Masyarakat dan Desa Departemen dalam Negeri ( 2009) Pemberdayaan ini menekankan bahwa orang memperoleh keterampilan, pengetahuan, dan kekuasaan yang cukup untuk mempengaruhi kehidupannya dan kehidupan orang lain yang menjadi perhatiannya (Suharto, 2005). Menurut Sunartiningsih (2004) menyebutkan proses pemberdayaan masyarakat yang dilakukan diharapkan mampu: Menganalisis situasi yang ada dilingkungannya, mencari pemecahan masalah berdasarkan kemampuan dan keterbatasan yang mereka miliki, meningkatkan kualitas hidup anggota, meningkatkan penghasilan dan perbaikan penghidupan di masyarakat, Mengembangkan sistem untuk mengakses sumber daya yang diperlukan.

Tujuan dari pemberdayaan masyarakat menunjuk pada keadaan atau hasil yang ingin dicapai oleh sebuah perubahan sosial, yaitu meningkatkan masyarakat yang tidak berdaya menjadi berdaya dan memperkuat kekuasaan atau mempunyai pengetahuan dan kemampuan dalam memenuhi kebutuhan hidupnya baik yang bersifat fisik, ekonomi, maupun sosial seperti mempunyai kepercayaan diri, mampu menyampaikan aspirasi, mempunyai mata pencaharian, berpartisipasi dalam kegiatan sosial, dan mandiri dalam melaksanakan tugas kehidupannya, (Suharto., 2005)

\section{Pendidikan sebagai Sarana Pemberdayaan Masyarakat}

Sedangkan menurut Prijono dan Pranarka (1996). pemberdayaan diartikan sebagai proses belajar mengajar yang merupakan usaha terencana dan sistematis yang dilaksanakan secara berkesinambungan baik bagi individu maupun kolektif, guna mengembangkan daya (potensi) dan kemampuan yang terdapat dalam diri individu dan kelompok masyarakat sehingga mampu melakukan transformasi sosial. 
Pemberdayaan masyarakat melalui Kelompok Usaha Bersama (KUBE) adalah sebuah upaya yang memungkinkan masyarakat dengan segala keberadaannya dapat memberdayakan dirinya. Dengan demikian, pusat aktivitas seharusnya berada ditangan masyarakat itu sendiri, dengan bertitik tolak dari masyarakat, dilaksanakan oleh masyarakat dan dimanfaatkan oleh masyarakat. Menurut Yunus dalam (Kusnadi, 2005). menyebutkan 5 prinsip sikap dasar yang patut diperhatikan agar pendidikan dapat dikatakan proses pemberdayaan, yaitu: (1) Kepedulian terhadap masalah, kebutuhan, dan potensi atau sumber daya manusia. (2) Kepercayaan timbal balik dari pelayan program dan dari masyarakat pemilik program. (3) Fasilitasi dalam membantu kemudahan masyarakat dalam berbagai proses kegiatan. (4) Adanya partipatif, yaitu upaya melibatkan peran serta semua komponen lembaga atau individu terutama warga belajar dalam proses kegiatan. Dan (5) Mengayomi peranan masyarakat dan hasil yang dicapainya.

\section{Kelompok Usaha Bersama ( KUBE )}

Kelompok merupakan kumpulan orang-orang yang mempunyai tujuan yang sama. Kelompok Usaha Bersama dapat diartikan sebagai sebuah kelompok yang beranggotakan orang-orang yang mempunyai tujuan untuk belajar berusaha melalui kegiatan tertentu. Peraturan Direktur Jenderal Perbendaharaan Nomor Per19/Pb/2005 Tentang Petunjuk Penyaluran Dana Bantuan Modal Usaha Bagi Keluarga Binaan Sosial Program Pemberdayaan Fakir Miskin Melalui Pola Pengembangan Terpadu Kelompok Usaha Bersama (KUBE) Dan Lembaga Keuangan Mikro (LKM), menyebutkan:

Kelompok Usaha Bersama (KUBE) adalah himpunan dari keluarga yang tergolong miskin yang dibentuk oleh masyarakat, tumbuh dan berkembang atas dasar prakarsanya sendiri, sehingga berinteraksi antara satu dengan yang lain dan tinggal dalam satu wilayah tertentu dengan tujuan untuk meningkatkan relasi sosial yang harmonis, dalam memenuhi kebutuhan Anggotanya, memecahkan masalah sosial ekonomi yang dialaminya dan menjadi wadah pengembangan usaha bersama. 


\section{METODE PENELITIAN}

Penelitian ini menggunakan pendekatan kualitatif karena peneliti bermaksud mendiskripsikan bagaimana pemberdayaan ekonomi kelompok usaha bersama untuk meningkatkan kesejahteraan masyarakat di Dusun Penangka Desa Sesaot. Metode pengumpulan data yang digunakan dalam penelitian kualitatif adalah observasi, wawancara dan dokumentasi. Untuk memperoleh data yang diharapkan dalam penelitian ini data dapat diperoleh dari berbagai sumber yaitu pengelola, anggota kelompok, dan keluarga dari anggota program Kelompok Usaha Bersama (KUBE). yaitu Menurut), untuk melakukan analisis data peneliti harus mengikuti beberapa tahapan. Tahapan tersebut yaitu reduksi data, penyajian data dan mengambil kesimpulan,(Faisal dan Moleong dalam Iskandar 2009). Sedangkan keabsahan data yang di gunakan yaitu teknik triangulasi digunakan dengan alasan bahwa dengan menggunakan teknik triangulasi dalam pengumpulan data, maka data yang diperoleh akan lebih konsisten, tuntas dan pasti (Sugiyono, 2009)

\section{HASIL PENELITIAN DANPEMBAHASAN}

Kelompok Usaha Bersama (KUBE) merupakan program dari Departemen Sosial melalui Program Kesejahteraan Sosial dalam rangka memantapkan penghapusan kemiskinan. Kelompok ini dilakukan dalam memberdayakan keluarga miskin. Dengan adanya program kelompok usaha bersama ini di harapkan mampu mengurangi permasalahan sosial yang ada di masyarakat.

Kelompok Usaha Bersama (KUBE) waroh merupakan salah satu kelompok yang dibentuk di Desa Sesaot pada 1 januari 2005 oleh ibu Mainah. Tujuan dari Kelompok Usaha Bersama (KUBE) Waroh adalah membangun sumber daya manusia. Tujuan yang lain diantaranya memperoleh pengetahuan dan keterampilan guna mewujudkan kualitas hidup dan meningkatkan kesejahteraan hidupnya serta meningkatkan kemampuan anggota dalam berinteraksi sosial dengan sesama 
anggota atau masyarakat lainnya sehingga menimbulkan kepedulian dan kesetiakawanan social.

Kegiatan produksi yang dilakukan kelompok usaha bersama (KUBE) Waroh sudah banyak mengalami kemajuan, hal itu dapat dilihat dari tingkat produksinya yang meningkat semula hanya $50 \mathrm{~kg}$ sehari sekarang kalo pas rame bisa menghabiskan 6 karung singkong dalam sehari. Kegiatan produksi kelompok usaha bersama (KUBE) Waroh sekarang juga lebih berfaritif dalam memproduksi produknya, yaitu antara lain; keripik (pisang,talas,singkong,umbi ungu, umbi madu, rumput laut), dodol (nangka,pisang), tape pisang, manisan (tomat,rumput laut,papaya). Pemasaran produknya yang semula hanya di sekitaran sesaot saja tapi sekarang sudah gampang menemui produknya di toko oleh-oleh se pulau Lombok serta di swalayan-swalayan ternama di Lombok barat dan kota mataram.

\section{Pendidikan sebagai Sarana Pemberdayaan Masyarakat Melalui Program pelatihan pembuatan aneka makanan ringan di Kelompok Usaha Bersama (KUBE) Waroh}

Salah satu kegiatan yang dilaksanakan di Kelompok Usaha Bersama (KUBE) Waroh sebagai wujud dari pemberdayaan masyarakat khususnya bagi kaum perempuan untuk meningkatkan kesejahteraan yaitu pelatihan pembuatan aneka makanan ringan. Dalam proses pelatihan yang di bimbing langsung oleh ibu Mainah ini setiap anggota diusahakan mengikuti semua proses pelaksanaanya. Pelatihan yang juga sebagai proses pendidikan non formal yang dilakukan kelompok usaha bersama (KUBE) Waroh tidak lain bertujuan untuk meningkatkan pengetahuan bagi anggotanya dan meningkatkan kualitas sumberdaya manusia agar lebih bersaing dalam dunia kerja.

Dari hasil wawancara yang saya lakukan mengenai program pelatihan yang dilaksanakan di Kelompok Usaha Bersama (KUBE) Waroh cukup berdampak pada meningkatnya pengetahuan para anggota kelompok usaha bersama (KUBE) Waroh. Setelah mengikuti program pelatihan di KUBE Waroh, sekarang mereka mampu atau mengerti bagaimana mengolah sesuatu menjadi lebih mempunyai nilai jual tinggi. 


\section{Program Keterampilan Kelompok Usaha Bersama (KUBE) Waroh}

Program yang dilaksanakan di Kelompok Usaha Bersama (KUBE) Waroh sebagai wujud dari pemberdayaan masyarakat khususnya bagi kaum perempuan untuk meningkatkan kesejahteraan salah satunya yaitu keterampilan membuat aneka makanan ringan. Tujuan dari pemberian keterampilan kepada kaum perempuan melalui pelatihan keterampilan pembuatan aneka makanan ringan adalah untuk membangun sumber daya manusia, meningkatkan kemampuan kaum perempuan dibidang keterampilan membuat makanan ringan, agar bakat dan minat yang dimiliki menjadi terasah dan dapat menciptakan daya saing dan peluang tenaga kerja.

Diharapkan melalui program keterampilan ini, khususnya kaum perempuan mempunyai skil untuk bersaing di dunia kerja dan mempunyai kesempatan kerja yang akan meningkatkan pendapatan mereka.

Dengan adanya program keterampilan yang dilaksanakan di Kelompok Usaha Bersama ini yang sebelumnya para kaum ibu-ibu belum mempunyai skil dalam mengolah bahan-bahan mentah, sekarang mereka mampu dalam mengolah bahan-bahan tersebut menjadi lebih bernilai ekonomis. Materi yang diberikan adalah bagaimana cara memilih ketela pohon yang berkualitas baik, mengupas ketela, memotong ketela, pisang menjadi irisan yang tipis, memberikan bumbu makanan, cara menggoreng,cara pengemasan sampai pada pemasaran.

\section{Dampak Program Kelompok Usaha Bersama (KUBE) Waroh}

Kelompok Usaha Bersama (KUBE) Waroh sudah bisa memberikan layanan pendidikan nonformal kepada kaum perempuan. Dalam pelaksanaan program Kelompok Usaha Bersama (KUBE) Waroh melibatkan banyak komponen, diantaranya pemerintah, swasta dan masyarakat, baik secara langsung maupun tidak langsung. Semenjak kelompok usaha bersama ini didirikan oleh ibu mainah dan ibu-ibu lainnya sejak 01 januari 2005 tentunya ada berbagai dampak yang dirasakan oleh ibu mainah beserta anggota kelompok usaha bersama lainya. 
Kelompok usaha bersama berperan sebagai wadah bagi masyarakat khusunya kaum perempuan untuk belajar usaha mandiri dan mengembangkan potensi diri. sehingga dapat menunjang perekonomian mereka. Hal itu dapat dibuktikan dari penuturan beberapa anggota kelompok usaha bersama yang dapat ditarik kesimpulan bahwa cukup efektifnya program kelompok usaha bersama ini dalam mengangkat perekonomian para anggota kelompok usaha bersama (KUBE) Waroh ini.

\section{Keberhasilan Kelompok Usaha Bersama (KUBE) Waroh dalam meningkatkan Kesejahteraan}

Keberhasilan program merupakan pencapaian hasil yang sesuai dengan tujuan yang telah ditetapkan. Keberhasilan program Kelompok Usaha Bersama (KUBE) Waroh dalam meningkatkan kesejahteraan anggota sudah dikatakan berhasil dengan kriteria atau indikator yang terlihat. Indikator keberhasilan Kelompok Usaha Bersama (KUBE) Waroh diantaranya mempunyai pengetahuan dan keterampilan membuat aneka olahan makanan ringan, meningkatnya kualitas hidup dan kesejateraan keluarga yang ditandai dengan mendapatkan kesempatan kerja, meningkatnya pendapatan, meningkatnya tingkat pendidikan.

Kualitas hidup dan kesejahteraan keluarga merupakan dua hal yang saling berkaitan. Mewujudkan kesejahteraan keluarga merupakan hal yang sulit jika tidak mempunyai kualitas hidup yang baik, kesadaran dan kemauan berusaha. Melalui Kelompok Usaha Bersama (KUBE) Waroh anggota mendapatkan ilmu yang dapat dijadikan bekal untuk bersaing di dunia kerja untuk mendapatkan tempat bekerja sebagai sumber penghasilan. Pengahasilan yang diperoleh anggota dapat digunakan untuk memenuhi kebutuhan yang dibutuhkan, mulai dari kebutuhan primer sampai kebutuhan yang bersifat sekunder. Terpenuhinya kebutuhan hidup sehari-hari menjadi tolok ukur tingkat kesejahteraan. Indikator meningkatnya kualitas hidup dan kesejahteraan antara lain adalah: 


\section{Mendapatkan Kesempatan Kerja}

Kesediaan tempat untuk magang seperti Kelompok Usaha Bersama (KUBE) Waroh untuk dimagangi, menularkan pengetahuan dan ketarampilan yang dimiliki kepada anggotanya di dasari oleh beberapa hal, diantaranya adalah: kesediaan, kemampuan, dan kemauan. Kemampuan yang dimilikinya menjadi ciri bahwa masyarakat mempunyai kualitas yang menjadikan nilai jual untuk bersaing di dunia kerja. Keberhasilan program Kelompok Usaha Bersama (KUBE) Waroh dalam menyediakan lapangan pekerjaan di Desa sesaot Dapat dilihat dari hasil wawancara bahwa program kelompok usaha bersama mampu menyediakan atau membuka kegiatan usaha baru bagi anggotanya. Dengan keyakinan dan kemauan untuk belajar yang ada dalam diri bisa membawanya ke dunia kerja dan bisa mendapatkan penghasilan yang dapat digunakan untuk memenuhi kebutuhan hidup. Hal itu terlihat dari anggota kelompok usaha bersama yang dulunya hanya ibu-ibu rumah tangga dan hanya lulusan smp tetapi mereka sekarang bisa mempunya kegiatan usaha.

\section{Meningkatnya pendapatan anggota kelompok usaha bersama (KUBE)}

\section{Waroh}

Tujuan dalam bekerja yaitu mendapatkan penghasilan yang dapat digunakan untuk memenuhi kebutuhan hidup. Kebutuhan hidup seperti menyekolah anak, membeli sembako, biaya kesehatan, dan kebutuhan yang lainnya yang tidak terduga. Kelompok Usaha Bersama (KUBE) Waroh ini berhasil dalam menjembatani dalam meningkatkan pendapatan anggotanya. dengan mengikuti kegiatan di Kelompok Usaha Bersama (KUBE) Waroh bisa meningkatkan penghasila. Dalam sehari anggota KUBE mampu mendapat Rp.50.000 sampai Rp.60.000, artinya dalam sebulan rata-rata mereka mendapat Rp. 1.500 .000 sampai Rp. 1.600.000 dengan catatan apabila mereka rajin bekerja. Dengan hasil yang diperoleh dapat digunakan untuk meringankan beban suami dalam memenuhi kebutuhan hidup dalam berkeluarga. Penghasilan tersebut diantaranya digunakan 
untuk menyekolahkan anak, membeli sembako, dan memenuhi kebutuhan lainnya juga.

\section{Meningkatnya tingkat pendidikan anggota kelompok usaha bersama (KUBE)} Waroh

Pengetahuan dan keterampilan merupkan dua hal yang saling melengkapi dan terkait satu sama lain. Tanpa pengetahuan, keterampilan tidak akan mudah dilaksanakan, karena keterampilan sebagai penunjang atau realisasi dari pengetahuan yang didapatkan. Hal semacam ini bisa didapatkan melalui proses belajar non formal seperti pelatihan-pelatihan keterampilan. Dari sini anggota kelompok usaha bersama di didik untuk mengembangkan potensi diri yang dimiliki. kelompok usaha bersama (KUBE) Waroh di atas dapat disimpulkan bahwa, pendidikan non formal seperti belajar mengolah hasil bumi seperti ketela pohon, umbi-umbian, serta buah-buahan menjadi aneka makanan ringan justru bisa dikatakan menjadi jurus ampuh dalam menciptakan lapangan kerja yang akan mendorong tingkat pendapatan keluarga. Ketika tingkat pendapatan keluarga meningkat tentunya akan mendorong mencapai pada titik kesejahteraan.

Dari beberapa indikator di atas, sudah jelas bahwa Kelompok Usaha Bersama (KUBE) Waroh telah mampu mencapai keberhasilannya dalam meningkatkan kesejahtraan bagi anggotanya. Kelompok Usaha Bersama (KUBE) Waroh sudah bisa menjadikan anggotanya yang sebelumnya tidak mempunyai pengetahuan dan keterampilan, sekarang sudah bisa memberikan pengetahuan bahkan menyediakan lapangan pekerjaan yang dapat menghasilan penghasilan sehingga membantu perbaikan keadaan ekonomi bagi anggota yang mengikuti program Kelompok Usaha Bersama (KUBE) Waroh.

\section{KESIMPULAN}

Berdasarkan dari hasil penelitian yang telah dilakukan, maka peneliti dapat menarik kesimpulan bahwa Program KUBE Waroh merupakan suatu kegiatan yang 
menjembatani masyarakat untuk mendapatkan pengetahuan, keterampilan dan pengalaman melalui suatu kelompok yang dibentuk secara bersama guna meningkatkan kualitas sumber daya manusia agar mampu memasuki dunia kerja, dimana hasil yang diperoleh bisa digunakan untuk meningkatkan kesejahteraan hidupnya.

Program KUBE Waroh terhadap anggota KUBE Waroh dapat memberikan manfaat yang positif bagi anggotanya, dilihat dari anggota yang sebelumnya tidak mempunyai kegiatan usaha sekarang mempunyai kegiatan usaha yang sekaligus juga berdampak pada perekonomian anggotanya yang sudah meningkat. Keberhasilan program KUBE Waroh ditandai oleh: anggota mempunyai dan meningkatnya pengetahuan dan keterampilan membuat aneka olahan makanan ringan, meningkatnya kualitas hidup dan kesejahteraan keluarga ditandai oleh: anggota KUBE mendapatkan kesempatan kerja, meningkatnya pendapatan anggota, meningkatnya tingkat pendidikan keluarga dari anggota.

\section{DAFTAR RUJUKAN}

Direktorat Jenderal Pemberdayaan Masyarakat dan Desa Departemen dalam Negeri. (2009). Pedoman Umum Pemberdayaan Masyarakat dan Desa. Jakarta:Gaung Persada.

Iskandar. (2009). Metodologi Penelitian Kualitatif. Jakarta: Gaung Persada.

Kusnadi. (2005). Pendidikan Keaksaraan; Filosofi, Strategi dan Implementasi. Jakarta: Depatemen Pendidikan Nasional.

Prijono dan Pranarka. (1996). Pemberdayaan: Konsep, Kebijakan, dan Implentasi. Jakarta: Centre For Strategic and International Studies.

Sugiyono. (2009). Memahami Penelitian Kualitatif. Bandung: Alfabeta .

Suharto. (2005). Membangun Masyarakat Memberdayakan Masyarakat. Bandung: PT. Refika Aditama.

Sunartiningsih. (2004). Pemberdayaan Masyarakat Desa melalui Institusi Lokal.Yogyakarta: Aditya Media. 